\title{
PARADYGMAT ROZWOJU REGIONALNEGO W ASPEKCIE PRZEDSIĘBIORCZOŚCI SPOŁECZNEJ
}

\begin{abstract}
Polityka regionalna, jest podstawą polityką europejskiej solidarności i obejmuje wszystkie regiony i miasta w Unii Europejskiej. Większość środków finansowania w ramach polityki spójności przeznaczona jest dla słabiej rozwiniętych krajów i regionów, tak aby wspierać niwelowanie dysproporcji gospodarczych, społecznych i terytorialnych.

Jednocześnie jest ona uzupełnieniem unijnej polityki spójności, w ramach realizacji strategii „Europa 2020” oraz ułatwia osiąganie podstawowych celów w odniesieniu do środowiska, jednolitego rynku, energii, inteligentnego i zrównoważonego wzrostu gospodarczego, zatrudnienia, eliminowania wyłączenia społecznego oraz badań naukowych i innowacji. ${ }^{2}$

Artykuł przedstawia nową strategię rozwoju Polski do 2030 roku, w tym także ogólne koncepcje i cele strategii rozwoju regionalnego, w odniesieniu do aktualnej Krajowej Strategii Rozwoju Regionalnego (KSRR). W oparciu o przeprowadzone badania, omówiono zagadnienia struktury, zasad funkcjonowania i uwarunkowań. Przedstawiono również opis stanu ilościowego podmiotów sektora ekonomii społecznej pod kątem szans ich rozwoju, źródeł finansowania działalności oraz współpracy z innymi podmiotami, dla realizacji działalności przedsiębiorczości społecznej - w odniesieniu do północnego regionu województwa śląskiego.

Słowa kluczowe: strategia rozwoju regionalnego, przedsiębiorczość społeczna, CIS, zarządzanie.
\end{abstract}

\section{WPROWADZENIE}

Misją polityki rozwoju regionalnego jest wzrost poziomu spójności wewnętrznej w ramach całej Unii, a spójność (kohezja) rozumiana jest w ujęciu ekonomicznym, społecznym i przestrzennym. Głównym celem zatem jest wspieranie zatrudnienia, rozwoju zrównoważonego, konkurencyjności przedsiębiorstw, wzrostu gospodarczego i jakości życia mieszkańców.

Najważniejsze przesłanki rozwoju polityki regionalnej, to przede wszystkim:

- rosnące zróżnicowanie regionalne wynikające $\mathrm{z}$ różnorodności warunków naturalnych,

\footnotetext{
${ }^{1}$ Dr Agata Kielesińska, Politechnika Częstochowska, Wydział Zarządzania, Katedra Regionalistyki i Zarządzania Ekorozwojem, 42-200 Częstochowa, ul. Armii Krajowej 36B Tel. 505 859229; e-mail: kielesinska@op.pl

${ }^{2}$ Polityka regionalna Unii Europejskiej zakłada osiągnięcie pięć celów do roku 2020: (1) 75\% osób z grupy wiekowej 20-64 lat ma znaleźć zatrudnienie; (2) 3\% unijnego PKB zostanie zainwestowane w badania naukowe i rozwój; (3) obniżenie emisji gazów cieplarnianych o 20\% (w stosunku do 1990 r., (przez pozyskiwanie 20\% energii ze źródeł odnawialnych i zwiększenie wydajności energetycznej o 20\%); (3) obniżenie wskaźnika osób przedwcześnie kończących naukę, poniżej 10\%; (4) zmniejszenie o co najmniej $20 \mathrm{mln}$ liczby osób ubogich lub zagrożonym ubóstwem i wykluczeniem społecznym.
} 
- przyspieszony rozwój gospodarczy wielu krajów i zmiany w podziale pracy,

- globalne tendencje integracyjne wymagające rozwiązywania problemów regionalnych,

- zagrożenia środowiska naturalnego wymaga zarządzania na poziomie lokalnym i regionalnym.

Celem opracowania jest przedstawienie strategii i koncepcji rozwoju regionalnego Polski oraz istoty przedsiębiorczości społecznej (jej podstaw prawnych i ekonomicznych aspektów prowadzonej działalności), jako czynnika inicjującego zaangażowanie mieszkańców w wspieraniu procesu lokalnego i regionalnego rozwoju społecznogospodarczego. Analizę krytyczną dokonano na podstawie szerokiego spektrum współczesnej literatury przedmiotu oraz w oparciu o udostępnione badania w zakresie struktury, zasad funkcjonowania i opisu stanu ilościowego podmiotów sektora ekonomii społecznej - w północnej części województwa śląskiego.

\section{NOWY PARADYGMAT POLITYKI REGIONALNEJ W ŚWIETLE} LITERATURY PRZEDMIOTU

Paradygmat $^{3}-$ w rozumieniu wprowadzonym przez filozofa Thomasa Kuhna ${ }^{4}-$ to zbiór pojęć i teorii stanowiących podstawy danej dziedziny nauki, za pomocą którego tworzy się teorie szczegółowe, zgodne z danymi doświadczalnymi i z dotychczasową wiedzą i spełniające określone warunki (np. istniejących dowodów). ${ }^{5}$ Jest on istotny dla badań naukowych, gdyż „żadna nauka przyrodnicza nie może być wyjaśniana bez zastosowania splecionych teoretycznych i metodologicznych poglądów pozwalających na wybór, ocenę i krytykę".

Paradygmat kieruje wysiłkiem badawczym społeczności naukowych i jest tym kryterium, które najbardziej ściśle identyfikuje obszary nauk. Fundamentalnym argumentem Kuhna jest to, że dla dojrzałej nauki typową drogą rozwojową jest kolejne przechodzenie w procesie rewolucji od jednego do innego paradygmatu. Gdy ma miejsce zmiana paradygmatu, „świat naukowy zmienia się jakościowo i jest jakościowo wzbogacany przez fundamentalnie nowe zarówno fakty, jak i teorie".

Kuhn argumentuje, że rewolucje naukowe są nieskumulowanym epizodem rozwojowym, podczas którego starszy paradygmat jest zamieniany w całości lub po części przez niezgodny z nim paradygmat nowszy. Ale nowy paradygmat nie może być zbudowany na poprzedzającym go, a raczej może go tylko zamienić, gdyż „instytucjonalna tradycja naukowa wyłaniająca się z rewolucji naukowej jest nie tylko niezgodna, ale też nieuzgadnialna $\mathrm{z}$ tą, która pojawiła się przed nią". ${ }^{6}$

\footnotetext{
${ }^{3}$ Paradygmat, przyjęty sposób widzenia rzeczywistości w danej dziedzinie, doktrynie itp., (słownik języka polskiego)

${ }^{4}$ Kuhn Thomas Samuel (amerykański fizyk, historyk i filozof nauki, twórca pojęcia paradygmatu naukowego). Struktura rewolucji naukowych, Wydawnictwo Fundacji Aletheia, (The Structure of Scientific Revolutions 1962), wyd II: 2001,

${ }^{5}$ Od tzw. dogmatu paradygmat odróżnia się m. innymi tym, że nie jest on dany raz na zawsze i podważa sens absolutnej słuszności, gdyż samo pojęcie ,absolutnej słuszności” nie ma charakteru naukowego.

${ }^{6}$ Kuhn utrzymywał także, że - wbrew obiegowym opiniom - typowi naukowcy nie są obiektywnymi i niezależnymi myślicielami, a są konserwatystami, którzy godzą się z tym, czego ich nauczono i stosują tę naukę (wiedzę) do rozwiązywania problemów zgodnie z dyktatem wyuczonej
} 
W myśl koncepcji Kuhna proces rozwoju nauki stanowi ewolucję od prymitywnych początków przez następujące kolejne stadia charakteryzujące się wzrastająca szczegółowością i coraz bardziej wyrafinowanym zrozumieniem przyrody. Kuhn dowodzi, że nauka nie jest jednostajnym, kumulatywnym pozyskiwaniem wiedzy. Zamiast tego nauka jest serią spokojnych okresów przerywanych przez gwałtowne intelektualne rewolucje, po których jeden koncepcyjny światopogląd jest zamieniany przez inny. Kuhn spopularyzował w tym kontekście termin paradygmat, opisywany przez niego jako w istocie zbiór poglądów podzielanych przez naukowców, zestaw porozumień o pojmowaniu zagadnień.

W ekonomii obowiązuje obecnie paradygmat wyrastający z ekonomii neoklasycznej, mówiący o samoregulującym mechanizmie rynku prowadzącym do optymalnej alokacji zasobów. Obszerna stosunkowo literatura przedmiotu ${ }^{7}$, odnosi się do różnych opisów problematyki rozwoju regionalnego oraz charakterystycznych czynników, barier i narzędzi sterowania jego rozwojem.

Dotychczasowe koncepcje rozwoju regionalnego opierają się na dwóch różnych podejściach:

- $\quad$ teorii rozwoju endogenicznego (wewnętrznego, oddolnego) oraz

- teorii rozwoju egzogenicznego (zewnętrznego, odgórnego indukowanego)

Powiązanie obydwu podejść (z których jedno zakłada ograniczenie zewnętrznej ingerencji $\mathrm{w}$ ramach polityki regionalnej, a drugie dostrzega potrzebę działania $\mathrm{z}$ zewnątrz), jako warunku uruchomienia procesów rozwojowych, wymusza zastosowanie różnych działań i różnych instrumentów na poszczególnych poziomach realizacji polityki regionalnej.

Nowa geografia ekonomiczna ${ }^{8}$, będąca kombinacją obydwu teorii, uwzględniająca cechy i tendencje rozwojowe zachodzące na różnych terytoriach, jest podstawą filozofii nowego paradygmatu polityki regionalnej. Uwypukla ona korzyści dużych, wysoko

przez nich teorii. Większość z nich w istocie jedynie składa układanki, celując w odkrywaniu tego, co i tak już jest im znane - „Człowiek, który usiłuje rozwiązać problem zdefiniowany przez istniejącą wiedzę i technikę nie ma szerszych horyzontów. Wie on co chce osiągnąć, i w zgodzie z tym projektuje swoje narzędzia i kieruje swoimi myślami”.

${ }^{7}$ Dorożyński T., Przyczyny regionalnych nierówności gospodarczych w świetle wybranych teorii, Studia Prawno-Ekonomiczne, t. LXXX, 2009

Górka M., Funkcje sieci w rozwoju regionów, Katolicki Uniwersytet Lubelski, Lublin, 2008

Grosse T.G., Przeglad koncepcji teoretycznych rozwoju regionalnego, ,

Studia Regionalne i Lokalne" 2002, nr 1 (8).

MRR Nowy paradygmat rozwoju - najnowsze trendy i perspektywy polityki regionalnej,

Warszawa, 2011

Sekuła A., Paradygmaty rozwoju lokalnego i regionalnego, Edukacja menedżerska w nowej gospodarce. Zarządzanie organizacją", red. A. Tubielewicz, Politechnika Gdańska,

Cetniewo 2001

Żuber P., Koncepcja nowej polityki regionalnej w perspektywie średniookresowej, MRR,

Katowice, 2009

${ }^{8}$ Twórca tzw. Nowej Geografii Ekonomicznej - teorii wyjaśniającej m.in. zjawiska związane z procesem globalizacji - a także Nowej Teorii Handlu Międzynarodowego, jest Paul Robin Krugman ekonomista amerykański. Za jej opracowanie otrzymał w 2008 r. Nagrodę Banku Szwecji im. Alfreda Nobla w dziedzinie ekonomii. 
wyspecjalizowanych terytoriów charakteryzujących się wykorzystaniem wysokiej technologii i elastycznymi rynkami pracy. W tej przestrzeni następuje stały proces rozwijania technologii przez nich wykorzystywanych oraz przyciąganie wyspecjalizowanej kadry, dzięki czemu następuje stałe wzmacnianie tendencji rozwojowych tych terytoriów. Istotnym jest także bezpośrednie zaangażowanie mieszkańców w lokalny i regionalny rozwój społeczno-gospodarczy, poprzez różne formy działalności ekonomii społecznej.

Modele oparte na teorii wzrostu endogenicznego uwzględniające ekonomię innowacji podkreślają, że w takich lokalizacjach może dochodzić do intensyfikacji związków między procesami tworzenia innowacji, procesami tworzenia wiedzy, jej asymilacji i uczenia się. Dodatkowo na koncentrację innowacyjnej działalności mają wpływ sprzyjające warunki instytucjonalne, wynikające ze zbioru instytucji kształtujących system innowacji i ich jakości. To właśnie na tych obszarach, przede wszystkim w dużych ośrodkach metropolitalnych wraz $\mathrm{z}$ ich zapleczem (obszarami metropolitalnymi), następuje koncentracja działalności gospodarczej i kumulacja wiedzy, i tym samym we współczesnym świecie to one są obszarami tworzenia wzrostu i zatrudnienia czyli podstawowych składników rozwoju .

Nowa geografia ekonomiczna i teorie rozwoju gospodarczego ukazują istnienie obszarów rdzeni (ang. core) i peryferii (ang. peripheries), które są rezultatem tendencji aglomeracji. Wg tej doktryny należy wykorzystywać koncentrację najważniejszych ogniw gospodarczych i przestrzennych, tj. układów metropolitalnych, i wspierać ich dalszą zdolność do rozwoju (przez uczestniczenie układów metropolitalnych w międzynarodowej wymianie dóbr, usług, kapitału i wiedzy, co wzmacnia ich konkurencyjność). Z drugiej strony, aby umożliwić inicjowanie procesów rozwojowych w obszarach peryferyjnych wymagana jest interwencja w dwóch obszarach. Potrzebne jest dążenie rozprzestrzeniania rozwoju do obszarów poza metropolitalnych (dyfuzja regionalna) oraz interwencja uzupełniająca może być terytorialnie ukierunkowana do tych obszarów, które są zagrożone trwałym regresem i postępującą marginalizacją, a nie w odniesieniu do tych, które notują wolniejsze, ale dodatnie tempo wzrostu . Proces dyfuzji zachodzi zatem jednocześnie $\mathrm{w}$ trzech wymiarach: międzynarodowym, krajowym i regionalnym.

$\mathrm{Z}$ pojęciem rozwoju bardzo silnie powiązane jest pojęcie konkurencyjności rozumianej jako zdolność do konkurowania (osiągania i utrzymywania przewag konkurencyjnych) oraz długookresowego, efektywnego wzrostu, a w efekcie jako zdolność do rozwoju oraz budowania dobrobytu.

Każde terytorium posiada własny, często bardzo zróżnicowany zestaw cech składających się na potencjał rozwojowy. Wykorzystanie tych zasobów w procesach rozwojowych danego terytorium (regionu czy innego obszaru funkcjonalnego, np. aglomeracji), powoduje zmiany ilościowe - rozumiane jako wzrost gospodarczy, czyli zwiększenie produkcji dóbr i usług wskutek ilościowego zwiększenia wykorzystywanych czynników produkcji oraz poprawy ich efektywności a tym samym zmiany jakościowe i strukturalne. Zdolność poszczególnych obszarów do konkurowania na rynku krajowym i globalnym jest uzależniona od zdolności do wykorzystania ich specyficznych potencjałów, tzn. od podjętych przez władze publiczne działań, które muszą uwzględniać działalność innych uczestników mających wpływ na wywołanie procesów rozwojowych na danym terytorium. 


\section{STRATEGIE ROZWOJU KRAJU}

Strategia zarządzania rozwojem (rys. 1) zawiera strategie: Długookresową (DSRK) i Średniookresową (ŚSRK), Strategie zintegrowane oraz Koncepcję Przestrzennego Zagospodarowania Kraju (KPZK).

Główną politykę i strategie rozwoju Polski określa Długookresowa Strategia Rozwoju Kraju DSRK, „Polska 2030. Trzecia fala nowoczesności”, kreujący trendy i scenariusze rozwoju społeczno-gospodarczego Polski, a także kierunki przestrzennego zagospodarowania kraju, do 2030 roku.

Rys. 1. System strategicznego rozwoju Polski

\section{DŁUGOOKRESOWA STRATEGIA ROZWOJU KRAJU}

\section{ŚREDNIOOKRESOWA STRATEGIA ROZWOJU KRAJU}

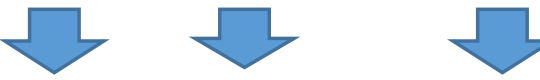

\section{STRATEGIE ZINTEGROWANE}

Strategia innowacyjności i efektywności gospodarki

Strategia rozwoju kapitału ludzkiego

Strategia rozwoju transportu

Strategia Bezpieczeństwo energetyczne i środowisko

Strategia Sprawne państwo

Strategia zrównoważonego rozwoju wsi, rolnictwa i rybactwa

Strategia rozwoju systemu bezpieczeństwa narodowego RP

Strategia rozwoju kapitału społecznego

Krajowa strategia rozwoju regionalnego

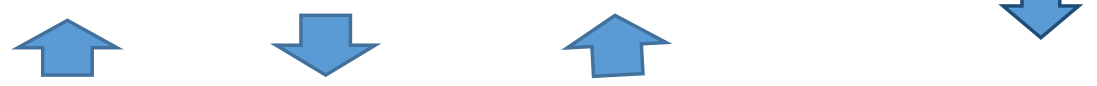

KONCEPCJA PRZESTRZENNEGO ZAGOSPODAROWANIA KRAJU

Źródło: MRR, Polska 2030, Dlugookresowa Strategia Rozwoju Kraju, 2013.

Natomiast Średniookresowa strategia rozwoju kraju ŚSRK- Strategia Rozwoju Kraju 2020 oraz 9 zintegrowanych strategii, wskazują zadania państwa i tworzą ramy dla interwencji strukturalnej w Polsce, przy wdrażaniu polityk unijnych, koncentrując się na potencjałach społeczno-gospodarczych i przestrzennych, które będą stymulowały rozwój ${ }^{10}$. Strategia ŚSRK integrując wokół celów i procesów rozwojowych wszystkie

\footnotetext{
${ }^{9}$ MRR, Polska 2030, 2013, Warszawa, Długookresowa Strategia Rozwoju Kraju:12.

${ }^{10}$ Strategia Innowacyjności i Efektywności Gospodarki, Rozwoju Kapitału Ludzkiego, Rozwoju Transportu, Bezpieczeństwo Energetyczne i Środowisko, Sprawne Państwo, Rozwoju Kapitału
} 
podmioty publiczne, a także środowiska społeczne i gospodarcze, zwraca uwagę na wymiar terytorialny działań i lepsze wykorzystanie potencjałów regionalnych. System ten obejmuje także wdrażane strategie ponadregionalne rozwoju kraju.

\section{KRAJOWA STRATEGIA ROZWOJU REGIONALNEGO (KSRR)}

Szczególną rolę w nowym systemie strategicznym rozwoju kraju spełnia Krajowa Strategia Rozwoju Regionalnego 2010-2020 (KSRR) ${ }^{11}$, wskazując zakres wsparcia terytorialnego, w ramach różnych polityk publicznych.

Założeniem KSRR jest wykorzystanie specyficznych atutów (tzw. potencjałów rozwojowych), które dawałyby szansę na wzrost gospodarczy i większe zatrudnienie oraz niwelowały różnice w poziomie rozwoju. Przyjęty model polaryzacyjno-dyfuzyjny w realizacji, który zakłada pełne wykorzystanie naturalnych procesów koncentracji i przepływów kapitału, osób i wiedzy, ogniskujących się w węzłach policentrycznej sieci osadniczej, przy jednoczesnym wzmacnianiu potencjału do absorpcji i dyfuzji procesów rozwojowych na obszarach położonych poza funkcjonalnymi obszarami miast. KSRR wyznacza też trzy cele szczegółowe. Dotyczą one:

- wzrostu konkurencyjności regionów - wykorzystanie endogenicznych potencjałów i posiadanych specjalizacji regionu, rozwijanie potencjałów największych miast i otaczających gmin w tworzeniu warunków do rozwoju przez pozostałe obszary. W miastach są szkoły wyższe, instytucje kultury i powstaje najwięcej miejsc pracy, innowacyjnych firm,

- niwelowania różnic w rozwoju poszczególnych obszarów kraju - w tym miast, które utraciły dotychczasowe funkcje społeczno-gospodarcze, obszarów wiejskich, obszarów przygranicznych oraz tych części Polski, które nie mają nowoczesnej sieci drogowej czy kolejowej,

- sprawnego zarządzania polityką rozwoju - m.in. większa rola województw w prowadzeniu polityki rozwoju, nowe narzędzia polityki regionalnej - kontrakty terytorialne, obserwatoria terytorialne, krajowe i regionalne fora terytorialne), które mają przyczynić się do osiągnięcia w/w celów ${ }^{12}$.

Krajowa Strategia Rozwoju Regionalnego (KSRR) zwraca uwagę na wymiar terytorialny podejmowanych działań, a zatem podkreśla znaczenie samorządu terytorialnego i innych podmiotów w rozwoju regionów i kraju.

W okresie do 2020 r. akcent strategiczny został położony w głównej mierze na wzmacnianie potencjałów, które w przyszłości zagwarantują długofalowy rozwój, a nie tylko na alokację środków bezpośrednio w dziedziny, w których występują największe deficyty, w ciągu najbliższych dziesięciu lat (rys. 2).

Społecznego, Rozwoju Systemu Bezpieczeństwa Narodowego RP, Zrównoważonego Rozwoju Wsi, Rolnictwa i Rybactwa. Krajowa Strategia Rozwoju Regionalnego KSRR 2010-2020: Regiony, Miasta, Obszary wiejskie.

${ }^{11}$ MRR, 2010, Warszawa, Krajowa Strategia Rozwoju Regionalnego 2010-2020: Regiony, Miasta, Obszary wiejskie: 6-7.

${ }^{12}$ Jednym z nich jest Kontrakt Terytorialny - mechanizm współpracy i koordynacji działań rządu oraz samorządów wojewódzkich. Kontrakty wskazują jakie działania podejmie rząd, a jakie będą wspierane z poziomu samorządowego (przez województwo, powiat, gminę). 
Rys. 2. Cele szczególowe KSRR

- wspomaganie konkurencyjności regionów

- budowanie spójności terytorialnej i przeciwdzialanie marginalizacji obszarów

- tworzenie warunków dla skutecznej i partnerskiej realizacji dzialań rozwojowych ukierunkowanych terytorialnie

Źródło: oprac. wg MRR, Krajowa Strategia Rozwoju Regionalnego 2010-2020.

Współczesne zarządzanie rozwojem wymaga nie tylko działań władzy publicznej i otwarcia się instytucji publicznych na rozwiązania zgłaszane od obywateli, a także partnerskiego zaangażowania społeczeństwa. System polegający na upodmiotowieniu społeczeństwa w procesach rozwoju wykorzystuje nowe instrumenty w tym m. innymi ekonomii społecznej ${ }^{13}$ tworzące społeczną wartość dodaną i zmniejszające skutki wykluczenia społecznego. Ekonomia społeczna jest działalnością gospodarczą łączącą w sobie cele społeczne i ekonomiczne, ale nadrzędnym celem nie jest w niej maksymalizacja zysku, a działania na rzecz ludzi, którzy nie są w stanie samodzielnie poradzić sobie na rynku pracy.

Sektor ekonomii społecznej (ES) obejmuje: ${ }^{14}$

- podmioty wsparcia ekonomii społecznej:

○ Centra Ekonomii Społecznej CES,

O Ośrodki Wsparcia Ekonomii Społecznej OWES,

○ Regionalne Ośrodki Polityki Społecznej ROPS,

- podmioty ekonomii społecznej:

a) Centra Integracji Społecznej CIS, Kluby Integracji Społecznej KIS,

b) Zakłady Aktywności Zawodowej ZAZ,

c) Warsztaty Terapii Zajęciowej WTZ,

d) Przedsiębiorstwa społeczne PES,

e) spółdzielnie socjalne, spółdzielnie pracy i inwalidów,

f) spółdzielnie o charakterze konsumenckim i wzajemnościowym,

g) organizacje pozarządowe z odpłatną działalnością oraz spółki z o.o. non profit

- operatorów wsparcia finansowego w zakresie ekonomii społecznej (tab. 1).

\footnotetext{
${ }^{13}$ Najważniejszym elementem ekonomii społecznej są tzw. przedsiębiorstwa społeczne (PES). Zgodnie z definicją zawartą w Rozporządzeniu Parlamentu Europejskiego i Rady w sprawie Programu Unii Europejskiej na rzecz przemian i innowacji społecznych, przedsiębiorstwo społeczne oznacza przedsiębiorstwo, którego głównym celem jest raczej wywarcie wpływu społecznego niż wygenerowanie zysków dla właścicieli i zainteresowanych stron. Działa ono na rynku, produkując towary i świadcząc usługi $\mathrm{w}$ innowacyjny sposób zgodny $\mathrm{z}$ duchem przedsiębiorczości, a także wykorzystuje nadwyżki głównie do osiągania celów społecznych..

${ }^{14}$ wg Krajowego Programu Rozwoju Ekonomii Społecznej i Wieloletniego regionalnego planu działań na rzecz promocji i upowszechnienia ekonomii społecznej oraz rozwoju instytucji sektora ekonomii społecznej i jej otoczenia w województwie śląskim na lata 2012-2020:18.
} 
Tabela 1. Operatorzy wsparcia finansowego dla ekonomii społecznej woj. śląskiego

\begin{tabular}{|c|c|c|c|}
\hline Tytul projektu & Operator & Instytucja prowadząca & Adres \\
\hline $\begin{array}{l}\text { Spółdzielnie } \\
\text { socjalne } \\
\text { drugiej generacji }\end{array}$ & $\begin{array}{l}\text { Stowarzyszenie } \\
\text { Współpracy } \\
\text { Regionalnej }\end{array}$ & $\begin{array}{l}\text { Fundacja Rozwoju } \\
\text { Przedsiębiorczości Społecznej } \\
\text { „Być Razem” }\end{array}$ & 40-008 Katowice \\
\hline $\begin{array}{l}\text { Inkubator } \\
\text { Społecznej } \\
\text { Przedsiębiorczości } \\
\text { Województwa } \\
\text { Śląskiego }\end{array}$ & $\begin{array}{l}\text { Miasto Gliwice } \\
\text { Gliwickie } \\
\text { Centrum } \\
\text { Organizacji } \\
\text { Pozarządowych } \\
\end{array}$ & $\begin{array}{l}\text { Bielsko-Biała, Dąbrowa } \\
\text { Górnicza, Częstochowa, } \\
\text { Tychy, Żory, Żorskie } \\
\text { Centrum Organizacji } \\
\text { Pozarządowych, Stow. CRIS, }\end{array}$ & 44-100 Gliwice \\
\hline $\begin{array}{l}\text { Spółdzielnie } \\
\text { socjalne } \\
\text { nowej ery }\end{array}$ & $\begin{array}{l}\text { Fundacja } \\
\text { Regionalnej } \\
\text { Agencji Promocji } \\
\text { i Zatrudnienia }\end{array}$ & $\begin{array}{l}\text { Spółdzielnia Socjalna } \\
\text { „RedHead” Fundacja }\end{array}$ & $\begin{array}{l}\text { 41-300 Dąbrowa } \\
\text { Górnicza }\end{array}$ \\
\hline
\end{tabular}

Źródło: ROPS Regionalny Ośrodek Polityki Społecznej Województwa Śląskiego, Ekonomia społeczna, Broszura Informacyjna, Katowice, czerwiec 2013.

W ramach JOWES są przewidziane realizacje następujących zadań:

- świadczenie profilowanych usług doradczych, edukacyjnych i biznesowych na rzecz efektywnego funkcjonowania podmiotów ekonomii społecznej,

- wsparcie dla osób wykluczonych lub zagrożonych wykluczeniem społecznym, w tym nabór osób fizycznych i osób prawnych zainteresowanych uzyskaniem dotacji na utworzenie przedsiębiorstwa społecznego i utworzeniem miejsc pracy oraz pozyskaniem dotacji na zakładanie i funkcjonowanie przedsiębiorstw społecznych,

- świadczenie na poziomie lokalnym usług służących rozwojowi organizacji obywatelskich i partycypacji społecznej oraz usług inkubacyjnych (działania animacyjne, spotkania animacyjne, diagnozowanie środowiska lokalnego w obszarze ekonomii społecznej, budowanie partnerstw rozwojowych, wspieranie jednostek samorządu terytorialnego w prowadzeniu dialogu obywatelskiego, wizyty studyjne, warsztaty dla liderów, inicjatywy upowszechniające ideę ekonomii społecznej,

- wsparcie działań i wdrażania długookresowych źródeł finansowania podmiotów ekonomii społecznej, inicjatyw rozwijających przedsiębiorczość społeczną,

- opracowanie i wdrożenie modeli biznesowych dla 8 podmiotów ekonomii społecznej wprowadzających nowy produkt lub nową usługę w ramach działalności odpłatnej pożytku publicznego lub działalności gospodarczej.

Cel działania JOWES: stworzenie przyjaznego klimatu dla rozwoju ekonomii społecznej w północnym subregionie województwa śląskiego poprzez wsparcie dla tworzenia nowych przedsiębiorstw społecznych jak i efektywne wsparcie już istniejących podmiotów ekonomii społecznej. 


\section{DIAGNOZA FUNKCJONOWANIA PODMIOTÓW EKONOMII SPOŁECZNEJ W SUBREGIONIE PÓŁNOCNYM WOJEWÓDZTWA SLACSKIEGO ${ }^{15}$}

Badanie przeprowadzone przez Jurajski Ośrodek Wsparcia Ekonomii Społecznej w Częstochowie służyło diagnozie stanu wyjściowego sektora ekonomii społecznej subregionu północnego województwa śląskiego. Celem określenia było odniesienia dla dalszych działań Ośrodka zmierzających do rozwoju podmiotów ekonomii społecznej.

Terenem badań objęte było Miasto Częstochowa oraz powiaty: częstochowski, kłobucki i myszkowski. W procesie badawczym wykorzystane zostały następujące techniki badawcze:

- ankiety telefoniczne i elektroniczne prowadzone z przedstawicielami podmiotów ekonomii społecznej;

- wywiady osobiste z przedstawicielami podmiotów ekonomii społecznej.

Zgodnie z bazą Głównego Urzędu Statystycznego na obszarze badania zarejestrowanych było na dzień 31.12.2014 r. 2080 podmiotów ekonomii społecznej, z połową z nich ankieterom udało się skontaktować i przeprowadzić badanie wśród 1011.

\section{STRUKTURA PODMIOTÓW EKONOMII SPOŁECZNEJ}

Spośród 1011 przebadanych podmiotów ekonomii społecznej aktywnie działających jest 828, a wśród nich: 677 to stowarzyszenia, 77 fundacje, 32 spółdzielnie różnego rodzaju, 16 osób prawnych lub jednostek organizacyjnych działających na podstawie przepisów o stosunku Państwa do Kościoła, 15 innych podmiotów, które spełniają definicję organizacji pozarządowej w rozumieniu przepisów o działalności pożytku publicznego i o wolontariacie, 10 spółdzielni socjalnych, 1 spółka non profit.

Dostępności struktur trzeciego sektora, mierzona liczbą organizacji na 10 tys. mieszkańców, najlepsza sytuacja jest w powiecie częstochowskim (16,9 podmiotów ekonomii społecznej na 10 tys. osób), niewiele gorsza w Mieście Częstochowa $(16,2)$ przy 14,3 w powiecie myszkowskim i 14 organizacji przypadających na 10 tys. mieszkańców w powiecie kłobuckim (rys. 3).

\footnotetext{
15 Jurajski Ośrodek Wsparcia Ekonomii Społecznej przeprowadził, w I kwartale 2015 r. w badanie diagnozujące potencjał sektora ekonomii społecznej na terenie swojego oddziaływania na dzień 31.12.2014 r. Głównym celem badania było zebranie informacji dotyczących sposobu działania, potencjału oraz potrzeb podmiotów działających w sektorze ekonomii społecznej, opis stanu ilościowego i jakości podmiotów ekonomii społecznej pod kątem szans ich rozwoju, stanu zatrudnienia pracowników, źródeł finansowania działalności, współpracy z innymi podmiotami.
} 
Rysunek 3. Liczba działających PES

na 10 tys. mieszkańców Polski / średnia woj. śląskiego / średnia powiatu ${ }^{16}$

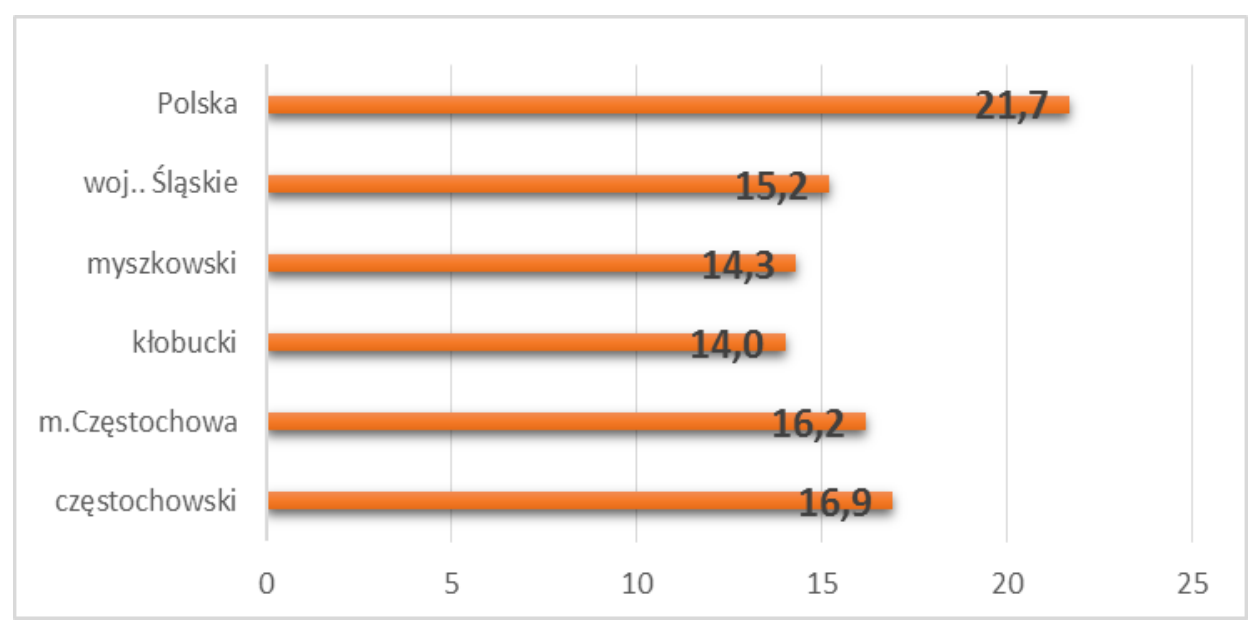

Źródło: Biuletyn Jurajskiego Ośrodka Wsparcia Ekonomii Społecznej w Częstochowie, numer 1, 11-12.2010.

Struktura badanych aktywnie działających organizacji ze względu na rodzaj działalności: 88,89 \% prowadzi działalność statutową nieodpłatną, 21,38\% działalność statutową odpłatną, 14,25 \% prowadzi działalność gospodarczą, 12,80 \% posiada status organizacji pożytku publicznego.

Dość niski wskaźnik organizacji prowadzących odpłatną działalność gospodarczą wskazał na potrzebę zaangażowania Ośrodka w podnoszenie świadomości przedstawicieli podmiotów ekonomii społecznej na temat korzyści, szans związanych z poszerzeniem rodzajów prowadzonej przez nich działalności i wzmożone wsparcie dla podmiotów ekonomii społecznej zainteresowanych ekonomizacją.

\section{NAJWAŻNIEJSZE DZIEDZINY DZIAŁALNOŚCI STATUTOWEJ}

Badane organizacje trzeciego sektora najczęściej jako główną dziedzinę swojej działalności wskazywały edukację i wychowanie (433 organizacje), sport (288 organizacji), ratownictwo i ochronę ludności (213 organizacji). Wynik ten związany jest z liczną reprezentacją stowarzyszeń prowadzących szkoły, działalność szkoleniową, stowarzyszeń kultury fizycznej oraz ochotniczych straży pożarnych w analizowanej zbiorowości trzeciego sektora. Charakterystyczną cechą podmiotów ekonomii społecznej jest duże rozwarstwienie zarówno w zakresie zasobów ekonomicznych, jak również społecznych. Stąd też zakres współpracy z podmiotami ekonomii społecznej powinien być rozpatrywany na różnych poziomach, a wsparcie ekonomii społecznej zawsze dostosowywane do indywidualnych potrzeb organizacji i celu, jaki chce ona osiągnąć.

\footnotetext{
16 Wg Raportu GUS, 2014, Warszawa, Trzeci sektor w Polsce, stowarzyszenia, fundacje...,
} w 2012:38. 
Jako najważniejsze dziedziny działalności stosunkowo licznie organizacje deklarowały także przeciwdziałanie problemom społecznym i wykluczeniu społecznemu (162 organizacje), kulturę i sztukę (155 organizacji), działalność charytatywną (150), promocję miasta/regionu (147 organizacji) oraz ochronę zdrowia (140 organizacji). Nieco rzadziej badane organizacje trzeciego sektora angażowały się w działalność obejmującą turystykę $\mathrm{i}$ wypoczynek (132 organizacje), ochronę środowiska(127 organizacji) oraz działalność na rzecz osób niepełnosprawnych (124 organizacje).

\section{ODBIORCY I ZASIEGG DZIALALNOŚCI STATUTOWEJ}

Analiza grup odbiorców omawianych organizacji wskazuje, że zdecydowanie najczęściej adresatami ich działań są dzieci i młodzież - grupa ta jest stałym odbiorcą działań 274 organizacji. Kolejnymi pod względem liczebności grupami beneficjentów okazały się być: lokalna społeczność (212 organizacji), wszyscy mieszkańcy obszaru, na którym działa organizacja (201 organizacji), osoby z niepełnosprawnością (92 organizacje).

Rozpatrując organizacje pod kątem zasięgu terytorialnego, na którym prowadzą działalność statutową $580 \mathrm{z}$ nich działa wyłącznie lokalnie (w granicach gminy), z tym, że $109 \mathrm{z}$ nich jako obszar działalności wskazało wyłącznie najbliższą okolicę na terenie, której funkcjonuje. 118 organizacji wskazało jako maksymalne pole zasięgu swojego działania województwo śląskie, natomiast 181 całą Polskę. 24 organizacje spośród badanych działają na terenie krajów Unii Europejskiej.

\section{EKONOMICZNY WYMIAR DZIALALNOŚCI PODMIOTÓW} EKONOMII SPOLECZNEJ

Wyniki badania wykazały, że źródłem przychodów, z którego najczęściej korzystały badane organizacje okazały się:

- $\quad$ składki członkowskie (594 organizacje),

- źródła samorządowe (436 organizacje),

- darowizny od osób fizycznych (325),

- darowizny od firm i instytucji (306).

Nieco mniejszą rolę $\mathrm{w}$ finansowaniu działalności badanych organizacji odgrywał przychody z przekazania $1 \%$ podatku (144 organizacje), przychody z kampanii, zbiórek publicznych (128 organizacji), przychody z działalności gospodarcze (98 organizacji) oraz zwroty kosztów w ramach odpłatnej działalności statutowej organizacji (73).

Stąd też duża rola Ośrodka w budowaniu niezależności ekonomicznej organizacji poprzez szeroki zakres wsparcia szkoleniowego, doradczego. Oceniając stałe miesięczne koszty funkcjonowania $25 \%$ organizacji zadeklarowało, że nie ponosi takich kosztów, natomiast u $46 \%$ badanych organizacji koszty te mieszczą się do $1500 \mathrm{zl}$. U $10 \%$ badanych organizacji miesięczne koszty są wyższe niż $15000 \mathrm{zł}$.

Zbadano również zasoby pracy, którymi dysponowały aktywne organizacje trzeciego sektora - 65,46 \% (542) badanych organizacji zadeklarowało, że nie zatrudnia pracowników. Wśród 286 organizacji zatrudniających pracowników łącznie zatrudnionych było 3014 osób, w tym na umowę o pracę - 1468 osób, na umowę cywilnoprawną - 1001 osób, na umowę wolontariacką -545 . 


\section{PODSUMOWANIE}

Reasumując, należy stwierdzić, iż współczesne zarządzanie rozwojem wymaga nie tylko działań władzy publicznej i otwarcia się instytucji publicznych na rozwiązania zgłaszane od obywateli, a także partnerskiego zaangażowania społeczeństwa.

System polegający na upodmiotowieniu społeczeństwa w procesach rozwoju wymaga nowych instrumentów zmniejszających skutki wykluczenia społecznego i tworzących społeczną wartość dodaną, w tym m. innymi ekonomii społecznej, która jest działalnością gospodarczą łączącą w sobie cele społeczne i ekonomiczne, a nadrzędnym celem nie jest w niej maksymalizacja zysku, ale działania na rzecz ludzi, którzy nie są w stanie samodzielnie poradzić sobie na rynku pracy. Istotną rolę $\mathrm{w}$ realizacji partnerstwa $\mathrm{z}$ instytucjami społeczeństwa obywatelskiego w oparciu o zasadę pomocniczości odgrywa zlecanie realizacji zadań publicznych organizacjom pozarządowym.

W okresie programowania 2014-2020 realizowane są przedsięwzięcia rozwoju sektora społecznego, poprzez wsparcie przedsiębiorczości ukierunkowanej na tworzeniu dodatkowych miejsc pracy oraz realizowania programów podwyższania kwalifikacji i doświadczenia zawodowego wśród osób bezrobotnych, ale także na tworzenie infrastruktury usług społecznych dla lokalnych społeczności.

Dla efektywnego wykorzystania ekonomii społecznej jest potrzebne włączenie się organizacji pozarządowych, które powinny współpracować z Jednostkami Samorządu Terytorialnego $\mathrm{w}$ realizacji lokalnych polityk społecznych $\mathrm{z}$ pozycji partnera, a nie podmiotu zależnego, co często się zdarza na terenach wiejskich.

Ekonomia społeczna jest propozycją nowego paradygmatu ekonomicznego, alternatywnego wobec formuły neoliberalnej. Wspomaga znacząco zatrudnienie, realizowane przez spółdzielnie socjalne, spółdzielnie pracy - angażując oddolnie społeczeństwo i rozwija działalność w ramach stowarzyszeń, aktywizuje, edukuje oraz stwarza osobom wykluczonym z życia społecznego, zawodowego szansę na powrót do społeczeństwa i doskonali ich umiejętności. Ekonomia społeczna stanowi równocześnie:

- element Europejskiego Modelu Społecznego w nowej polityce integracji społecznej $;^{17}$

- element polityki wzrostu zatrudnienia poprzez wypełnianie przestrzeni lokalnej w sferze usług społecznych oraz umożliwia zatrudnienia grup szczególnie zagrożonych na rynku;

- instrument rozwoju społeczności lokalnej, w zakresie usług użytku publicznego.

\section{BIBLIOGRAFIA}

[1] GUS, 2014, Warszawa, Raport Trzeci sektor w Polsce, stowarzyszenia,....w 2012:38

[2] MRR, 2013, Warszawa, Długookresowa Strategia Rozwoju Kraju, Polska 2030 ,Trzecia fala nowoczesności”:12,

[3] MRR, 2010, Warszawa, Krajowa Strategia Rozwoju Regionalnego 20102020, Regiony, Miasta, Obszary wiejskie:6-7,

[4] MRR, 2012,Warszawa, Krajowy Program Rozwoju Ekonomii Społecznej, Projekt:13

\footnotetext{
${ }^{17}$ MRR, 2012,Warszawa, Krajowy Program Rozwoju Ekonomii Społecznej, Projekt:13
} 
[5] MRR 2013, Katowice, Krajowy Program Rozwoju Ekonomii Społecznej i Wieloletniego regionalnego planu działań na rzecz promocji i upowszechnienia ekonomii społecznej oraz rozwoju instytucji sektora ekonomii społecznej i jej otoczenia w województwie śląskim na lata 2012-2020:18

[6] Ustawia $\mathrm{z}$ dnia 6 grudnia $2006 \mathrm{r}$. o zasadach prowadzenia polityki rozwoju (Dz.U. z 2009 r. Nr 84, poz. 712, z późn. zm.) oraz w przyjętym przez Radę Ministrów dokumencie „Założenia systemu zarządzania rozwojem Polski”.

[7] ROPS 2013, Katowice, Regionalny Ośrodek Polityki Społecznej woj. Śląskiego, Ekonomia społeczna, Broszura Informacyjna:4 i dalsze,

[8] ROPS, 2015, Katowice, Regionalny Program Rozwoju Ekonomii Społecznej w woj. śląskim do roku 2020:13 i dalsze, Biuletyn JOWES w Częstochowie, 2010, numer 1:3-7.

\section{THE PARADIGM OF REGIONAL DEVELOPMENT IN TERMS OF SOCIAL} ENTREPRENEURSHIP

Regional policy is the basis for the policy of European solidarity, and covers all regions and cities in the European Union. The majority of funding under the cohesion policy is designed for the less developed countries and regions, so as to support bridging the disparities between the economic, social and territorial. At the same time, it is complementary to the EU's cohesion policy, in the framework of the implementation of the Europe 2020 strategy and facilitates the achievement of the fundamental objectives in relation to the environment, the single market, energy, smart and sustainable economic growth, job creation, eliminate social exclusion and research and innovation.

This article presents a new strategy for the development of Polish by 2030, including general concepts and objectives of the regional development strategy, with regard to the current national strategy for regional development (KSRR). Based on the research, discusses the structure, functioning and policy conditionalities and quantitative description of the State of the sector of social economy for opportunities for their development, financing activities and cooperation with other actors. for the implementation of the social entrepreneurship activities in relation to the northern region of Silesia.

Keywords: the strategy of regional development, social entrepreneurship, CIS, management.

DOI:10.7862/rz.2017.hss.6

Przesłano do redakcji: styczeń 2017

Przyjęto do druku: marzec 2017 
